KS. PIOTR MAJER

Wydział Prawa Kanonicznego

Uniwersytetu Papieskiego Jana Pawła II w Krakowie

ORCID: 0000-0002-9516-8839

\title{
CZY ADHORTACJA „AMORIS LAETITIA” ZMIENIŁA KAN. 915 KPK?
}

Treść: - 1. Niejasne nauczanie Amoris laetitia. - 2. Interpretacja biskupów Regionu Duszpasterskiego Buenos Aires. - 3. Amoris laetitia w opozycji do kan. 915 KPK? 4. - Grzech ciężki. - 5. Trwanie z uporem w grzechu. 6. Jawność grzechu. - Konkluzje.

\section{Niejasne nauczanie Amoris laetitia}

Posynodalna adhortacja apostolska papieża Franciszka Amoris laetitia o miłości w rodzinie z 19 marca 2016 r. ${ }^{1}$ jest podsumowaniem dwóch zgromadzeń Synodu Biskupów poświęconych rodzinie, które odbyły się w październiku 2014 i 2015 roku. Jeszcze przed tymi zgromadzeniami w całym Kościele żywo dyskutowane było zagadnienie dopuszczenia do Komunii Świętej osób, które po zawarciu małżeństwa i rozwodzie cywilnym zawarły nowe (cywilne) związki: niektórzy, wspierając się argumentami natury moralnej i sakramentalnej, proponowali (albo przynajmniej dopuszczali) złagodzenie dotychczasowej doktryny i dyscypliny ${ }^{2}$, wyrażanych

${ }^{1}$ AAS 108 (2016), s. 311-446. Przekład polski zaaprobowany przez Sekretariat Stanu Stolicy Apostolskiej, Wydawnictwo M, Kraków 2016. W dalszym ciągu używamy skrótu AL.

${ }^{2}$ Zob. F.R. Aznar GiL, Uniones matrimoniales irregulares. Doctrina y pastoral de la Iglesia, Salamanca 1993, s. 205-220; P. GóRAlCzy K, Powtórne związki małżeńskie 
zwłaszcza w adhortacji Jana Pawła II Familiaris consortio ${ }^{3}$ oraz innych dokumentach kościelnych ${ }^{4}$, inni stali na stanowisku, że niedopuszczanie osób żyjących more uxorio poza ważnym małżeństwem wynika z prawa Bożego i należy do niezmiennego magisterium Kościoła ${ }^{5}$.

w teologicznym i etycznym świetle, Ząbki 1995, s. 184-230; T. KANI A, L'ammissibilità all'Eucaristia dei divorziati risposati: l'insegnamento della Chiesa e la discussione teologico-morale contemporanea, Roma 1997, s. 105-130; J. WERCKMEISTER, Access to the Sacraments for Remarried Divorcees, Revue de Droit Canonique, 48 (1998), s. 59-78; W. Hryniewicz, Blask miłosierdzia, Kraków 2015; Z. Janczewski, Przyjmowanie Eucharystii przez osoby żyjace w małżeństwach niesakramentalnych, w: Reddite ergo qua sunt caesaris caesari et qua sunt Dei Deo. Studia in honorem prof. Josephi Krukowski dedicata, red. M. Sitarz, P. Stanisz, H. Stawniak, Lublin 2015, s. 408-412.

3 JAN PAWE€ II, Adhortacja apostolska „Familiaris consortio” o zadaniach rodziny chrześcijańskiej w świecie współczesnym, 22.11.1981, Watykan 1981, nr 84.

${ }^{4}$ Jan PAWEŁ II, Adhortacja apostolska „Reconciliatio et paenitentia” do episkopatu, duchowieństwa i wiernych po Synodzie Biskupów o pojednaniu i pokucie w dzisiejszym posłannictwie Kościoła, 2.12.1984, Watykan 1984, nr 34; Kongregacja DOKTRYNY WIARY, List na temat przyjmowania Komunii świętej przez wiernych rozwiedzionych i żyjacych w nowych zwiazkach, 14.09.1994, L'Osservatore Romano. Wydanie polskie, 15 (1994), nr 11, s. 49-52; PApieska Rada Ds. Tekstów PrawNYCH, Deklaracja dopuszczaniu do Komunii Świętej rozwiedzionych, którzy zawarli nowy związek, 24.06.2000, L'Osservatore Romano. Wydanie polskie, 21 (2000), nr 10, s. 55-56. Tradycyjne stanowisko Kościoła wobec rozwiedzionych, którzy zawarli nowe związki prezentują m.in. F.R. AzNAR GIL, Uniones matrimoniales irregulares..., s. 191-205; P. Góralczy K, Powtórne związki..., s. 171-183; T. KAniA, L'ammissibilità..., s. 71-84; W. GóRALsKi, Problem udziału w życiu sakramentalnym osób żyjących w niekanonicznych związkach małżeńskich, Roczniki Nauk Prawnych, 14 (2004), zesz. 2., s. 97-107; J. GRĘźLIKOWsKI, Wymiar prawny pozostawania katolika w zwiąku niesakramentalnym, Forum Iuridicum, 4 (2005), s. 159-188; T. RozkruT, Ochrona Eucharystii a zakaz dopuszczania do Komunii świętej osób trwających z uporem w jawnym grzechu ciężkim, Annales Canonici, 1 (2005), s. 36-44; R. KANTOR, To Bóg jest miłością a nie miłość bogiem. Małżéstwo, nieprawidłowe związki, duszpasterstwo niesakramentalnych, Tarnów 2009; U. Nowick A, Komunia dla rozwodników? Refleksje na kanwie wypowiedzi Prefekta Kongregacji Nauki Wiary z 23 października 2013 r., w: Reddite ergo..., s. 532-546.

${ }^{5}$ Zob. G. Müller, Świadectwo mocy łaski. O nierozerwalności małżeństwa i debacie dotyczacej dopuszczenia do sakramentów osób rozwiedzionych żyjacych w nowych związkach, w: Pozostać w prawdzie Chrystusa. Małżeństwo i komunia w Kościele katolickim, red. R. Dodaro, Poznań 2015, s. 143-159; V. DE PAolis, Rozwiedzeni 
Prezentacja rozmaitych poglądów w tej dziedzinie miała miejsce, co oczywiste, podczas obrad Synodu - zarówno na auli synodalnej, jak i w innych kościelnych środowiskach ${ }^{6}$.

Dyskusja nad znaczeniem niektórych sformułowań adhortacji Amoris laetitia w przedmiocie ewentualności dostępu do Komunii Świętej osób rozwiedzionych, które żyją w nowych związkach nie jest zamknięta. Część komentatorów - moralistów, kanonistów, hierarchów kościelnych - interpretuje postanowienia adhortacji posynodalnej w duchu dotychczasowego rozumienia nauczania Kościoła: Amoris laetitia właściwie w niczym nie zmieniła opartej na prawie Bożym doktryny - bo nie mogła tego uczynić - i dlatego nie można dopuścić do Stołu Pańskiego osób, które po rozwodzie zawarły nowe związki, niemające waloru ważnego małżeństwa, pozostających w sytuacji obiektywnego grzechu ciężkiego, chyba że postanowią żyć we wstrzemięźliwości seksualnej „jak brat z siostrą”. Inni z lektury papieskiego dokumentu wyciągają zgoła odmienne wnioski: skoro w adhortacji dopuszcza się, iż po należytym rozeznaniu konkretnej

żyący w nowych związkach a sakramenty, w: Pozostać w prawdzie Chrystusa..., s. $175-204$.

${ }^{6}$ Zob. F. AzNAr GiL, El debate sinodal (2014) sobre la situación eclesial de los fieles divorciados y casados de nuevo civilmente, Apollinaris 87 (2014), s. 447-485; P. Kroczek, Duszpasterska troska o rodziny zranione, w: Droga do „Amoris laetitia” (Annales Canonici Monographiae, nr 5), red. P. Kroczek, J. Krzywda, A. Sosnowski, Kraków 2017, s. 141-158; J. Ku PCZAK, Źródła sporu o „Amoris laetitia”, Poznań 2018, s. $75-266$.

${ }^{7}$ Zob. W. Gór Alski, Adhortacja apostolska „Amoris laetitia” papieża Franciszka. Prezentacja dokumentu z komentarzem do nn. 300-308, Płock 2016, s. 52-77; W. Góralski, Problem dostępu do Komunii świętej katolików rozwiedzionych i żyjacych $w$ małżeństwie cywilnym, w: Małżeństwo i rodzina w prawie kanonicznym i w prawie polskim, red. J. Krukowski, M. Sitarz, K. Gręźlikowski, Lublin 2017, s. 87-108; J. KRAJCZYŃsKI, Rozeznawanie sytuacji osób rozwiedzionych żyjących w nowych zwiazkach. Praktyczny komentarz do „Amoris laetitia”, Kraków 2017, s. 44-45, 61-62; J. Krajczyński, Droga rozeznawania. Pomoc dla osób rozwiedzionych żyjących w nowych związkach, Ius Matrimoniale 28 (2017), nr 2, s. 40-42; G.L. MüLLER, Dlaczego adhortacja „Amoris Laetitia” może i powinna być rozumiana $w$ sensie ortodoksyjnym, w: R. Buttiglione, Przyjacielska odpowiedź krytykom „Amoris Laetitia”, Kraków 2018, s. 5-30. 
sytuacji mężczyzny i kobiety żyjących w związku tylko cywilnym i uwzględnieniu „okoliczności łagodzących” można uznać, że w danej sytuacji nie ma poważnej winy „nawet gdy chodzi o dyscyplinę sakramentalną"8 i „dlatego nie można już powiedzieć, że wszyscy, którzy są w sytuacji tak zwanej «nieregularnej», żyją w stanie grzechu śmiertelnego, pozbawieni łaski uświęcającej"9, przeciwnie, nawet pośród pewnej obiektywnej sytuacji grzechu osoba taka może żyć w łasce Bożej, a dla wzrostu w życiu łaski i miłości może otrzymywać pomoc Kościoła, „w pewnych przypadkach mogłaby to być również pomoc sakramentów"10 - można dopuścić takie osoby do sakramentów pokuty i Eucharystii1" . Jeszcze inni w komentarzach do Amoris laetitia są tak samo niejednoznaczni, jak enigmatyczny jest tekst samej adhortacji i ostrożnie wolą nie artykułować wyraźnie żadnego stanowiska ${ }^{12}$.

Ze względu na niejasną wymowę rodzącą wątpliwości w tak istotnej kwestii tekst papieski jest oceniany krytycznie ${ }^{13}$. Wskazuje się nawet na konieczność jego urzędowej interpretacji ${ }^{14}$. Wypada

${ }^{8}$ Zob. AL, nr 300, przyp. 336.

${ }^{9} \mathrm{AL}, \mathrm{nr} 301$.

${ }^{10}$ Zob. AL, nr 305 i przyp. 351.

${ }^{11}$ Zob. Z. Janczewski, Udzielanie Komunii św. osobom rozwiedzionym? Analiza adhortacji „Amoris laetitia” papieża Franciszka, Prawo Kanoniczne 59 (2016) nr 2, s. 48-58; A. Muszala, Rozeznawanie w „Amoris laetitia” papieża Franciszka, w: Rozeznanie - przeszłość, teraźniejszość, przyszłość, red. Sz. Drzyżdżyk, M. Gilski, Kraków 2019, s. 221-251.

${ }^{12}$ Zob. P. SteczKowski, Dopuszczenie do Komunii Świętej osób żyjących po matżeńsku bez małżeństwa - norma czy subiektywna ocena?, w: Dyskusje nad „Amoris laetitia” (Annales Canonici Monographiae, nr 6), red. P. Kroczek, Kraków 2017, s. 78-93. Do takich „ostrożnych” głosów można zaliczyć także wydane przez Konferencję Episkopatu Polski Wytyczne pastoralne do adhortacji „Amoris laetitia”, 9.06.2018, Wiadomości KAI. Biuletyn Katolickiej Agencji Informacyjnej, 17.06.2018, nr 24, s. 8-13.

${ }^{13}$ Zob. W. Gór Alski, Adhortacja apostolska..., s. 50-52.

${ }^{14}$ Zob. W. Gór alski, Potrzebna urzędowa wykładnia. O właściwa interpretację rozdziału VIII adhortacji apostolskiej papieża Franciszka „Amoris laetitia”, Niedziela, r. 2016, nr 45, 6.11.2016, s. 28-29; J. Dyduch, Adhortacja „Amoris laetitia”twórcza kontynuacją adhortacji „Familiaris consortio”?, w: Dyskusje..., s. 43-44. 
zadać pytanie, dlaczego Franciszek nie zdecydował się na bardziej wyraziste wyrażenie magisterium? Można przypuszczać, że papież chciał uniknąć odbioru wskazań zawartych w adhortacji jako generalnej normy zachowań we wszystkich (zasadniczo) przypadkach i dlatego powstrzymał się od formułowania przepisu o charakterze prawnym. Zresztą wyraźnie dał do zrozumienia, że „nie należy oczekiwać od Synodu ani też od tej adhortacji nowych norm ogólnych typu kanonicznego, które można by stosować do wszystkich przypadków"15. Mogłoby to grozić niebezpieczeństwem uogólnienia, tymczasem dla tak delikatnej materii papież wybrał drogę rozeznania (via discretionis) ${ }^{16}$, pozwalającą duszpasterzom oceniać każdy przypadek z osobna. Franciszek nie nakazuje, by udzielać Komunii Świętej osobom rozwiedzionym żyjącym w nowych związkach, ale dopuszcza to w niektórych przypadkach ${ }^{17}$, pod warunkiem uzyskania $\mathrm{w}$ procesie osobistego rozeznania indywidualnej sytuacji danej osoby moralnego przekonania, że nie jest w stanie poważnej winy.

\section{Interpretacja biskupów Regionu Duszpasterskiego Buenos Aires}

Za urzędową wykładnię przepisów Amoris laetitia, które choć nie w sposób powszechny, wskazuje drogę umożliwienia osobom, które po rozwodzie cywilnym zawarły nowe związki, na przystępowanie do Komunii Świętej, można uznać list papieża Franciszka skierowany w odpowiedzi na dokument biskupów Regionu Duszpasterskiego Buenos Aires. Pasterze argentyńscy wydali 5 września 2016 r. zwięzłe wskazania na temat podstawowych zasad aplikacji rozdziału VIII Amoris laetitia ${ }^{18}$. Czytamy w nich m.in., że adhortacja nie uprawnia

\footnotetext{
${ }^{15} \mathrm{AL}, \mathrm{nr} 300$. Zob. też AL, nr 304.

${ }^{16}$ Termin „rozeznanie” jest jednym z kluczowych słów nowej adhortacji. Zob. obszerne studium poświęcone temu zagadnieniu: Rozeznanie - przeszłość, teraźniejszość, przyszłość, red. Sz. Drzyżdżyk, M. Gilski, Kraków 2019.

${ }^{17}$ Zob. P.L. Travers, "Amoris Laetitia» and Canon 915: a merciful return to the «letter of the law», Periodica 107(2018), s. 300.

${ }^{18}$ Región Pastoral Buenos Aires, Criterios básicos para la aplicación del capitulo VIII de Amoris laetitia, 5 września 2016 r., polskie tłumaczenie: https://www.
} 
do mówienia o wyrażeniu zgody na dostęp małżonków rozwiedzionych i żyjących w nowych związkach do Komunii Świętej, ale raczej $\mathrm{o}$ „procesie rozeznawania” $\mathrm{z}$ udziałem duszpasterza. Rozeznawanie to nie musi koniecznie prowadzić do sakramentów, lecz może skierować takie osoby ku innym formom ściślejszego włączenia w życie Kościoła. Jeżeli w konkretnych warunkach danej pary jest to wykonalne, można takim osobom zaproponować życie we wstrzemięźliwości seksualnej, zgodnie ze wskazaniami św. Jana Pawła II zawartymi w Familiaris consortio. Inną drogą jest pomoc w stwierdzeniu nieważności małżeństwa, o ile są ku temu podstawy prawne. Jeżeli nie jest to możliwe i „jeśli dochodzi się do rozpoznania, że w konkretnym przypadku istnieją okoliczności łagodzące odpowiedzialność i winę (por. AL, 301-302), szczególnie jeśli bierze się pod uwagę dobro dzieci z nowego związku, Amoris laetitia otwiera możliwość przystąpienia do sakramentów: pojednania i Eucharystii (por. AL przypisy 336 i 351). One dzięki sile łaski przyczyniają się do dalszego dojrzewania i wzrostu takich osób”. Takiej możliwości nie można jednak rozumieć w sensie nieograniczonego dostępu do sakramentów dla osób żyjących w sytuacjach nieprawidłowych albo uznania, że jakakolwiek sytuacja zawsze to usprawiedliwia. Proponuje się natomiast rozeznanie, które pozwoli ocenić odpowiednio każdy przypadek z osobna.

Dokument biskupów argentyńskich doczekał się nie tylko czysto grzecznościowego podziękowania i uznania ze strony Biskupa Rzymu, który w odpowiedzi (udzielonej w formie listu apostolskiego z 5 września 2016 r.) podkreślił, że „pismo jest bardzo dobre i w pełni wyjaśnia sens ósmego rozdziału Amoris laetitia. Nie ma innych interpretacji”, ale z polecenia Franciszka został opublikowany (wraz z papieską odpowiedzią) w urzędowym organie Stolicy Apostolskiej Acta Apostolicae Sedis ${ }^{19}$ oraz na stronie internetowej Watykanu. Co

deon.pl/religia/wiara-i-spoleczenstwo/art,1248,list-biskupow-ws-amoris-laetitia-pelny-tekst.html (dostęp 10.06.2019). Zgodnie z kan. $433 \$ 1$ KPK region kościelny to zespół kilku sąsiadujących ze sobą prowincji kościelnych (metropolii).

${ }^{19}$ AAS 108 (2016), s. 1071-1074. 
więcej, papież Franciszek nadał obu opublikowanym dokumentom rangę magisterium autentycznego ${ }^{20}$.

Z pewnością forma publikacji dokumentu argentyńskich biskupów i walor, jaki w ten sposób chciał mu nadać papież zasługuje na pogłębione studium - Czy wraz z listem Franciszka stanowi autentyczną wykładnię niejasnych wskazań Amoris laetitia? ${ }^{21}$ Czy poprzez swoistą „nostryfikację" papieską ów lokalny dokument stał się źródłem prawa obowiązującego w całym Kościele? Nie można jednak ignorować tego, że Biskup Rzymski wyraźnie włączył ów dokument do autentycznego magisterium, któremu - zgodnie z kan. 752 KPK - należy okazywać „religijne posłuszeństwo rozumu i woli” ${ }^{22}$.

\section{Amoris laetitia w opozycji do kan. 915 KPK?}

Amerykański kanonista, świecki wykładowca z Wyższego Seminarium Najświętszego Serca Pana Jezusa w Detroit, Edward N. Peters, $\mathrm{w}$ prowadzonym przez siebie blogu internetowym poświęconym prawu kanonicznemu: In the Light of the Law, poddał analizie skutki

\footnotetext{
${ }^{20}$ Stanowi o tym reskrypt Sekretarza Stanu ex audientia Sanctissimi z 5 czerwca 2017 r.: „Summus Pontifex decernit ut duo Documenta quae praecedunt edantur per publicationem in situ electronico Vaticano et in Actis Apostolicae Sedis, velut Magisterium authenticum". AAS 108 (2016), s. 1074.

${ }^{21}$ Należy pamiętać, że w myśl kan. $16 \$ 1 \mathrm{KPK}$ „w sposób autentyczny ustawy interpretuje ustawodawca oraz ten, komu on zlecił władzę autentycznego interpretowania".

${ }^{22}$ Wprawdzie dokument biskupów argentyńskich nie stał się formalnie dokumentem papieskim, ale w AAS został umieszczony w dziale Acta Francisci Pp. (w interpretacji należy uwzględniać regułę: a rubro ad nigrum valet illatio). Głównym dokumentem pozostaje list apostolski papieża (dokument biskupów z Argentyny jest oznaczony jako additum ad epistulam), w którym Franciszek wypowiedział się wyraźnie, że interpretacja dokonana w Criterios básicos jest jedyną właściwą wykładnią Amoris laetitia. Nawet wobec wątpliwości co do rangi magisterialnej dokumentu biskupów argentyńskich, nie ma wątpliwości, że list apostolski papieża stanowi magisterium authenticum, któremu należy okazywać religijne posłuszeństwo rozumu i woli i podporządkować się mu (kan. $752 \mathrm{KPK}$ ). Warto zauważyć, że oba dokumenty - biskupów argentyńskich i papieski - są datowane na ten sam dzień: 5 września 2016 r.
} 
prawne zamieszczenia w Acta Apostolicae Sedis dokumentu argentyńskich biskupów wraz z listem apostolskim papieża Franciszka ${ }^{23}$. Zdaniem Petersa, niezależnie od znaczenia prawnego, jakie może być nadane tej publikacji, przeważający jest kan. 915 KPK, który zabrania dopuszczać do Komunii Świętej „ekskomunikowanych i podlegających interdyktowi, po wymierzeniu lub deklarowaniu kary, jak również innych osób trwających $\mathrm{z}$ uporem w jawnym grzechu ciężkim". Dopóty przepis ten nie zostanie wyraźnie uchylony, znowelizowany albo zmieniona zostanie jego wykładnia w drodze interpretacji autentycznej per modum legis ${ }^{24}$, kanon 915 zachowuje moc prawną. Ponieważ ani list apostolski papieża Franciszka z 5 września 2016 r., ani dokument biskupów argentyńskich, ani sama adhortacja Amoris laetitia o kan. 915 nie wspominają, przepis ten nadal wiąże wszystkich szafarzy Komunii Świętej, bowiem ustawa nie traci swej mocy przez to, że się o niej milczy.

Peters podnosi także, że forma dokumentu papieskiego - zwykły list apostolski, a nie list apostolski motu proprio - nie wskazuje na wolę nowelizacji wspomnianego kanonu przez Franciszka. Tak samo - jego zdaniem - Amoris laetitia pozbawiona jest typowego charakteru ustawy, nie jest dokumentem natury prawnej, i z tej racji nie może zmieniać obowiązującego przepisu.

Czy rzeczywiście kan. 915 KPK sprzeciwia się wskazywanej w adhortacji Amoris laetitia możliwości przystępowania - po starannym rozeznaniu duszpasterskim sytuacji poszczególnych osób - do Stołu Pańskiego tych, którzy znajdują się w małżeńskich sytuacjach określanych jako „nieregularne” albo „nieprawidłowe”? Przepis ten zabrania dopuszczania do Komunii Świętej m.in. „osób trwających z uporem w jawnym grzechu ciężkim”. Istotnie, zarówno przed 1983 r.

${ }^{23}$ E. Peters, On the appearance of the pope's letter to the Argentine bishops in the Acta Apostolicae Sedis, https://canonlawblog.wordpress.com/2017/12/04/on-the-appearance-of-the-popes-letter-to-the-argentine-bishops-in-the-acta-apostolicae-sedis/, dostęp 10.06.2019. Podobne stanowisko wyraził autor w artykule: The Canonical Position of „Amoris Laetitia”, Fellowship of Catholic Scholars Quarterly 40(2017), nr 1-2, s. 15-19.

${ }^{24}$ Zob. kan. $16 \S 2$ KPK. 
(w odniesieniu do kan. $855 \$ 1$ KPK 1917, który nakazywał oddalanie od Eucharystii osób „jawnie niegodnych”, o ile nie okażą wyraźnej skruchy i rzetelnej poprawy oraz nie naprawią zgorszenia ${ }^{25}$ ), jak i po reformie Kodeksu Prawa Kanonicznego, do tej kategorii osób zaliczano „konkubinariuszy" ${ }^{26}$ czy też tych, którzy po rozpadzie małżeństwa i rozwodzie cywilnym zawarli nowe związki ${ }^{27}$. Mimo pojawiających się postulatów, by złagodzić surowość przepisu ${ }^{28}$, uwzględniając stopień osobistej winy, Kościół stał na niezmiennym

${ }^{25}$ Kan. 855 \$ 1 KPK 1917: „Arcendi sunt ab Eucharistia publice indigni, quales sunt excommunicati, interdicti manifestique infames, nisi de eorum poenitentia et emendatione constet et publico scandalo prius satisfecerint".

${ }^{26}$ Zob. A. Vermeersch, J. Creusen, Epitome Iuris Canonici cum comentariis ad scholas et ad usum privatum, t. II, Mechliniae - Romae 1949, s. 79; H. Jone, Commentarium in Codicem Iuris Canonici, t. II, Paderborn 1954, s. 99. Należy pamiętać, że w dawnej nomenklaturze kościelnej unikano nazywania małżeństwa cywilnego „małżeństwem”, a osób żyjących w związku tylko cywilnym „małżonkami”. Zob. P. MAJER, Zawarcie małżeństwa kanonicznego bez skutków cywilnych (kan. 1071 $\$ 1,2^{\circ}$ Kodeksu Prawa Kanonicznego), Wydawnictwo Naukowe PAT, Kraków 2009, s. 113.

${ }^{27}$ Np. art. 6.1 .2 motu proprio Jana Pawła II Iusti iudicis, 28 czerwca 1988 r., AAS 80 (1988), ss. 1258-1261, stanowi, iż z listy adwokatów Kurii Rzymskiej mają być natychmiast wykluczeni, „ci którzy żyją w konkubinacie albo zawarli tylko cywilny związek lub trwają w innym jawnym grzechu ciężkim” („vel aliter manifesto in gravi pecato perseverant”), z czego wynika, że pożycie w konkubinacie lub małżeństwie tylko cywilnym jest trwaniem w ,jawnym grzechu ciężkim”.

${ }^{28}$ Jeszcze podczas prac nad reformą KPK w 1978 r. niektórzy z konsultorów proponowali, aby w kanonie znalazł się tekst przewidujący możliwość dopuszczania do Komunii Świętej osób rozwiedzionych żyjących w ponownych związkach. Propozycji tej jednak nie przyjęto, ponieważ wszyscy zgodzili się, iż właściwa do rozstrzygnięcia tej kwestii nie jest Komisja, ale Stolica Apostolska. Zob. Communicationes 13 (1981), s. 412. Podczas dyskusji nad projektem całego Kodeksu w 1981 r. uznano, że zakaz dopuszczania do Eucharystii zawarty w kanonie z całą pewnością dotyczy także rozwiedzionych, którzy zawarli nowe związki: „Certo ceritus textus respiciat etiam divortiatos et renuptiatos”. Pontificia Commissio Codici IURis CANONICI RECOGNOSCENDO, Relatio complectens synthesim animadversionum ab Em.mis atque Exc.mis Patribus Commissionis ad novissimum schema Codicis Iuris Canonici exhibitarum, cum responsionibus a secretaria et Consultoribus datis, Città del Vaticano 1981, s. 214. Szerzej na temat prac legislacyjnych nad dzisiejszym kan. 
stanowisku, iż zakaz ten wypływa z prawa Bożego, które uznaje seksualne pożycie poza małżeństwem za obiektywny grzech ciężki ${ }^{29}$. Wobec pojawiających się interpretacji łagodzących zakaz wypływający z kan. 915, które uznawano za niebezpieczne, urząd nauczycielski Kościoła reagował zdecydowanie.

W świetle nauczania papieża Franciszka zawartego w adhortacji Amoris laetitia należy zastanowić się, czy brzmienie kan. 915 powinno ulec zmianie, by dostosować się do nowych wypowiedzi magisterialnych, czy też - przeciwnie - stwierdzenia papieskiego dokumentu nie dają się pogodzić z przepisem zawartym w Kodeksie św. Jana Pawła II? Inną opcją, którą należy rozważyć jest ewentualność nowelizacji dotychczasowej wykładni kan. 915, tak by bez zmiany treści, był on do pogodzenia z możliwością dopuszczenia do Eucharystii osób żyjących more uxorio poza ważnym małżeństwem. Odpowiedzi na te pytania uzależnione są od tego, czy wobec sformułowań Amoris laetitia takie osoby są objęte hipotezą przepisu, a więc, czy należą do kategorii „osób trwających z uporem w jawnym grzechu ciężkim”?

Dokonajmy zatem analizy tekstualnej elementów kanonu 915 KPK istotnych dla analizowanego zagadnienia. Zanim zostaną omówione trzy kryteria zawarte w hipotezie normy: ciężkość grzechu, upór oraz jawność, należy przypomnieć, iż przepis ów nie dotyczy wprost wiernego przystępującego do Komunii Świętej ${ }^{30}$, ale szafarza, do którego należy „dopuszczenie” (lub nie) - ne admittantur - do Eucharystii. Szafarz dokonuje oceny według kryteriów zewnętrznych, bo tylko

915 zob. W. Kowal, The Non-Admission of the Divorced and Remarried Persons to Holy Communion: Canon 915 Revisited, Studia Canonica 49 (2015), s. 418-427.

${ }^{29}$ Katechizm Kościoła Katolickiego w n. 2384 stanowi, iż małżonek żyjący po rozwodzie w nowym związku znajduje się „w sytuacji publicznego i trwałego cudzołóstwa”.

${ }^{30}$ Dotyczy go natomiast kan. $916 \mathrm{KPK}$ - „Temu, kto ma świadomość grzechu ciężkiego, nie wolno bez uprzedniej sakramentalnej spowiedzi odprawiać Mszy świętej ani przyjmować Ciała Pańskiego, chyba że istnieje poważna racja i nie ma sposobności wyspowiadania się; w takim jednak przypadku ma pamiętać o tym, że jest obowiązany wzbudzić akt żalu doskonałego, który zawiera w sobie zamiar wyspowiadania się jak najszybciej”. 
takie są dlań dostępne ${ }^{31}$. Przystępujący do Komunii Świętej natomiast podejmuje decyzję w oparciu o osąd własnego sumienia - qui conscius est. Szafarz Komunii Świętej - kapłan, diakon, szafarz nadzwyczajny ma obowiązek dopuścić do Stołu Pańskiego każdego, komu prawo tego nie zabrania ${ }^{32}$. Domniemywa się, że każdy, kto pragnie przyjąć Eucharystię, spełnia ku temu warunki - zakaz należałoby udowodnić, w myśl zasady: quilibet praesumitur bonus, nisi malus certo probetur ${ }^{33}$.

\section{Grzech ciężki}

Chociaż pojęcia „grzech" $i$ „grzech ciężki” nie należą do kategorii prawnych, słowo grzech występuje w Kodeksie Prawa Kanonicznego ponad dwadzieścia razy ${ }^{34}$. Grzech ciężki (czyli śmiertelny) to według Katechizmu Kościoła Katolickiego grzech, „który dotyczy materii poważnej i który nadto został popełniony z pełną świadomością i całkowitą zgodą" 35 . „Wymaga pełnego poznania i całkowitej zgody, zakłada także zgodę na tyle dobrowolną, by stanowił on wybór osobisty ${ }^{36}$. Nie jest zadaniem szafarza Komunii Świętej dokonywanie oceny, czy wina moralna przystępującego do Eucharystii jest ciężka coram Deo. Szafarz dokonuje oceny w zakresie zewnętrznym, a ciężkość grzechu, o której mowa w kan. 915, jest ciężkością „materialną” dotyczy bowiem takiej materii, która jest ciężka obiektywnie, czyli wewnętrznie (z natury) ${ }^{37}$.

\footnotetext{
${ }^{31}$ Nie mógłby np. odmówić udzielenia Eucharystii kapłan, który wie, że jako spowiednik przed chwilą odmówił udzielenia rozgrzeszenia osobie przystępującej do Komunii Świętej.

${ }^{32}$ Zob. kan. 912 oraz kan. $843 \$ 1$ (przy zastrzeżeniu, że drugi przepis odnosi się do „świętych szafarzy”, a więc nie obejmuje szafarzy nadzwyczajnych).

${ }^{33}$ Zob. J. HENDRIKs, "Ad sacram communionem ne admittantur...» Adnotationes in can. 915, Periodica 79(1990), s. 164.

${ }^{34}$ Zob. kan. 849, 865, 915, 916, 959-960, 962-963, 966, 977, 981, 982, 983, 984, 987, 988, 989, 991, 992-993, 1007, 1357, 1387, 1397, 1401.

${ }^{35} \mathrm{KKK}, \mathrm{nr} 1857$.

${ }^{36}$ Zob. KKK, nr 1859.

${ }^{37}$ Zob. J. HeNDRIKs, «Ad sacram communionem ne admittantur...»..., s. 169-171. Chodzi tu o grzechy, o których Jan Paweł II w nr. 17 adhortacji Reconciliatio et paenitentia z 2 grudnia 1984 r. pisał: „Synod ten nie tylko powtórzył to, co stwierdził
} 
Wprawdzie Katechizm przypomina dobitnie, że „akt płciowy powinien mieć miejsce wyłącznie w małżeństwie; poza nim stanowi zawsze grzech ciężki i wyklucza z Komunii sakramentalnej” ${ }^{38}$, to jednak papież Franciszek w Amoris laetitia wskazuje na pewne „okoliczności łagodzące” ${ }^{39}$, które powinny być wzięte pod uwagę w ocenie konkretnej sytuacji - „stopień odpowiedzialności nie jest równy w każdym przypadku" ${ }^{40}$. Mnogość sytuacji, jakie niesie z sobą życie, może prowadzić do wniosku, że choć obiektywnie osoby żyjące w nowych związkach nie zachowują norm wynikających z istotnych przymiotów małżeństwa: jego nierozerwalności i jedności, implikującej obowiązek

i ogłosił sobór Trydencki o istnieniu i naturze grzechów śmiertelnych i powszednich, ale pragnął przypomnieć, że grzechem śmiertelnym jest ten, który dotyczy materii poważnej i który nadto został popełniony z pełną świadomością i całkowitą zgodą. Należy dodać - jak uczynił to Synod - że niektóre grzechy z racji swej materii są $z$ natury ciężkie i śmiertelne. Istnieją więc akty, które jako takie, same w sobie, niezależnie od okoliczności, są zawsze wielką niegodziwością ze względu na przedmiot. Akty te, jeśli spełnione z wystarczającą świadomością i dobrowolnie, są zawsze ciężką winą".

${ }^{38} \mathrm{KKK}, \mathrm{nr} 2390$. To dobitne sformułowanie pojawia się w Katechizmie w kontekście „wolnych związków”, w których „mężczyzna i kobieta odmawiają nadania formy prawnej i publicznej współżyciu zakładającemu intymność płciową". Pojęcie to „odnosi się do różnych sytuacji, takich jak: konkubinat, odmowa małżeństwa jako takiego, niezdolność do podjęcia trwałych i ostatecznych zobowiązań”. Małżeństwo cywilne zawarte po rozwodzie przez jednego lub obojga małżonków nie należy wprawdzie do wolnych związków, choć i ono jest określane jako sytuacja „publicznego i trwałego cudzołóstwa” (KKK, nr 2384). Niemniej jednak sytuacji osób żyjących w małżeństwie cywilnym „nie można stawiać na równi z sytuacją tych, którzy współżyją bez żadnego związku, tu bowiem istnieje przynajmniej jakieś zobowiązanie do określonej i prawdopodobnie trwałej sytuacji życiowej” (Jan Paweł II, Familiaris consortio, nr 82)

${ }^{39}$ Zob. AL, nr 301-303. Nie są to jednak okoliczności łagodzące albo zwalniające z odpowiedzialności za popełnienie przestępstwa, bowiem zakaz, o którym mowa w kan. 915 nie jest sankcją za popełnienie przestępstwa, ale konsekwencją teologiczną sytuacji. Tymczasem jeden z autorów w artykule poświęconym Amoris laetitia zatrzymuje się nad okolicznościami łagodzącymi wyliczanymi w kan. 1324. Zob. G. LICCIARDI, Il capitolo VIII dell'Esortazione Apostolica "Amoris laetitia” tra logica pastorale e diritto canonico, Laurentianum 58 (2017), s. 393-395.

${ }^{40} \mathrm{AL}, \mathrm{nr} 300$. 
wyłączności czy wierności, to jednak mogą ponosić różny rodzaj winy, a czasem mogą być od niej całkowicie wolne. Nie zawsze bowiem można, bez cienia wątpliwości, utrzymywać, że chodzi o w pełni świadomy, dobrowolny, osobisty wybór człowieka, wypełniający znamiona kwalifikacji danego czynu jako grzech ciężki ${ }^{41}$.

Oczywiście, wobec takiej interpretacji może się pojawić - i rzeczywiście pojawia się ${ }^{42}$ - zarzut sytuacjonizmu i subiektywizmu etycznego. „Zgodnie z taką koncepcją grzech przestaje być rzeczywistością teologiczną, a na pierwszy plan wysuwa się aspekt psychologicznosocjologiczny" ${ }^{43}$. Tym bardziej, że w Deklaracji Papieskiej Rady ds. Interpretacji Tekstów Prawnych z 24 czerwca 2000 r. wyraźnie przypominano, iż w ocenie dokonywanej przez szafarza Komunii Świętej, który mógłby ewentualnie podjąć decyzję o niedopuszczeniu do Eucharystii osoby należy brać pod uwagę "grzech ciężki, rozumiany w sensie obiektywnym, ponieważ szafarz Komunii nie jest w stanie ocenić winy subiektywnej" ${ }^{44}$. Zwłaszcza w kontekście nauczania św. Jana Pawła II zawartego w encyklice Veritatis splendor o czynach „wewnętrznie złych” ze względu na ich przedmiot: „Jeśli czyny są wewnętrznie złe, dobra intencja lub szczególne okoliczności mogą łagodzić ich zło, ale nie mogą go usunąć: są to czyny «nieodwracalnie» złe, same z siebie [...] okoliczności lub intencje nie zdołają nigdy przekształcić czynu ze swej istoty niegodziwego ze względu na przedmiot w czyn «subiektywnie» godziwy lub taki, którego wybór można usprawiedliwić"45.

Niemniej jednak papież Franciszek w Amoris laetitia wyraźnie naucza, iż „ze względu na uwarunkowania i czynniki łagodzące możliwe jest, że pośród pewnej obiektywnej sytuacji grzechu osoba, która

${ }^{41}$ Zob. A. Muszala, Rozeznawanie..., s. 225-232.

${ }^{42}$ Najgłośniejszym echem odbiły się Dubia czterech kardynałów (19.09.2016 r.): R.L. Burke, W. Brandmüllera, J. Meisnera oraz C. Caffarry. Omawia je m. in. G. LICCIARdi, Il capitolo VIII..., s. 395-399.

${ }^{43}$ M. Machinek, Logika inkluzji papieża Franciszka. Pytanie otwarte na marginesie adhortacji „Amoris laetitia”, Forum Teologiczne 18 (2017), s. 202-203.

${ }^{44}$ Papieska Rada ds. Tekstów Prawnych, Deklaracja..., nr 2.a.

${ }^{45}$ Jan PAWE€ II, Encyklika Veritatis splendor, nr 81. 
nie jest subiektywnie winna albo nie jest w pełni winna, może żyć w łasce Bożej ${ }^{46}$, może kochać, a także może wzrastać w życiu łaski i miłości, otrzymując w tym celu pomoc Kościoła”, a „w pewnych przypadkach mogłaby to być również pomoc sakramentów”" Dlatego komentatorzy papieskiej adhortacji w oparciu o zawarte w niej treści uważają, iż wśród osób, które po rozwodzie zawarły nowe związki są takie, które nie żyją w stanie grzechu śmiertelnego i nie są pozbawione łaski uświęcającej ${ }^{48}$.

\section{Trwanie $z$ uporem $w$ grzechu}

Kanon 915 zabrania dopuszczania do Komunii Świętej tych, którzy $\mathrm{z}$ uporem trwają w jawnym grzechu ciężkim (,in manifesto gravi peccato obstinate perseverantes“). Upór ma miejsce wówczas, gdy ktoś zdecydowanie nie chce zmienić swojego sposobu życia ${ }^{49}$. Nie wystarcza zatem jeden odosobniony czyn, choćby bez wątpliwości wypełniał znamiona grzechu ciężkiego, wymaga się natomiast „trwania w grzechu”, a więc pewnej powtarzalności czy trwałej sytuacji.

Choć sformułowanie obstinate perseverantes tłumaczy się w języku polskim jako „trwający z uporem”, należy pamiętać, że nie chodzi tu o „upór”, o którym mowa w prawie karnym i który w języku łacińskim wyrażany jest rzeczownikiem contumacia, a przymiotnikiem contumax. Kan. $1347 \$ 1$ stanowi np., że „cenzury nie można ważnie wymierzyć bez wcześniejszego jednego przynajmniej upomnienia, by winny odstapił od uporu, i bez dania mu odpowiedniego czasu na poprawę". Aby można było mówić, iż ktoś trwa z uporem w grzechu

\footnotetext{
${ }^{46}$ Tymczasem, według nauki Katechizmu Kościoła Katolickiego, grzech śmiertelny „pociąga za sobą utratę miłości i pozbawienie łaski uświęcającej, to znaczy stanu łaski” (KKK, nr 1861).

${ }^{47}$ AL, nr 305 i przyp. 351.

${ }^{48}$ Zob. np. Z. JANCZEwski, Udzielanie Komunii św. osobom rozwiedzionym? Analiza adhortacji „Amoris laetitia” papieża Franciszka, Prawo Kanoniczne 59 (2016) nr 2, s. 41-58; F. Coccopalmerio, Radość miłości. Przewodnik po ósmym rozdziale adhortacji „Amoris laetitia” papieża Franciszka, Kraków 2017, s. 15-39.

${ }^{49}$ Zob. E. Szczot, Dopuszczanie do Komunii świętej wiernego katolika podlegającego normie kan. 915 KPK, Roczniki Nauk Prawnych 8 (1998), s. 209.
} 
ciężkim, o czym mowa w kan. 915, nie wymaga się wcześniejszego upomnienia przez duszpasterza i okazania jawnego sprzeciwu wobec tego upomnienia, tak by dopiero brak reakcji mógł pozwolić na niedopuszczenie do Komunii Świętej ${ }^{50}$.

W przypadku osób rozwiedzionych żyjących w nowych związkach cywilnych istotnie mamy do czynienia nie tyle z jednorazowym przewinieniem moralnym, pojedynczym grzechem (np. doprowadzeniem do rozwodu czy zawarciem nowego związku), ile z sytuacją trwałą. Czy jednak można bez żadnej wątpliwości stwierdzić, że takie osoby zdecydowanie nie chcą zmienić sposobu życia, wykazują złą wolę, w pełni dobrowolnie trwają w grzechu ciężkim, nie mając żadnej woli zmiany swej sytuacji? Wprawdzie oczekiwanym zachowaniem w ich położeniu byłoby rozstanie się, ale już św. Jan Paweł II w adhortacji Familiaris consortio przyznawał, że w pewnych sytuacjach mężczyzna i kobieta żyjący w nowym związku cywilnym nie moga, z ważnych powodów - np. ze względu na pochodzącą z prawa naturalnego powinność wychowania dzieci - uczynić zadość obowiązkowi rozstania się ${ }^{51}$. Skoro zatem „nie mogą” (a nie tylko „nie chcą”) się rozstać ${ }^{52}$, nie można bez żadnej wątpliwości twierdzić o złej woli i uporczywym trwaniu w grzechu - nawet jeśli tacy mężczyzna i kobieta nie są w stanie wyrzec się w nowym związku pożycia seksualnego, co Familiaris consortio przedstawiała jako jedyną dla nich drogę dopuszczenia do Eucharystii. Tym bardziej, gdyby jedna ze stron była gotowa do takiego wyrzeczenia, a druga nie godziłaby się na to ${ }^{53}$.

\footnotetext{
${ }^{50}$ Przypominała o tym Deklaracja Papieskiej Rady ds. Tekstów Prawnych z 24 czerwca 2000 r. wobec opinii wyrażanych przez niektórych autorów. Jednak nawet po jej ogłoszeniu niektórzy kanoniści nadal dopatrywali się niespójności w rozumieniu sformułowania „Z uporem”. Zob. J.J.M. Foster, Sacramental Law: Selected Developments in Twenty-Five Years of Praxis, The Jurist 69(2009), s. 498-501.

${ }^{51}$ Zob. FC, nr 84.

${ }^{52} \mathrm{AL}, \mathrm{nr} 302$ - „W pewnych okolicznościach ludzie napotykają na poważne trudności, by działać inaczej”.

${ }^{53}$ W AL, nr 296 papież pisze o tych, którzy „cierpią z powodu stanu, w jakim się znajdują".
} 
Papież Franciszek przywołuje i rozwija myśl Jana Pawła II w nr. 298 Amori laetitia, pisząc o tych, którzy trwają w nowym związku, „który umocnił się z czasem, z nowymi dziećmi, ze sprawdzoną wiernością, wielkodusznym poświęceniem, zaangażowaniem chrześcijańskim”, ale również ze „świadomością nieprawidłowości swojej sytuacji i wielką trudnością, by cofnąć się wstecz bez poczucia w sumieniu, że popadłoby się w nowe winy". Byłoby wręcz niesprawiedliwe sądzić, że wszystkie, bez wyjątku, osoby żyjące po rozwodzie w nowych związkach, dobrowolnie i w złej wierze trwają w sytuacji grzechu. Droga duszpasterskiego rozeznania proponowana przez papieża Franciszka zmierza ku temu, by w pewnych przypadkach móc złą wolę w takich sytuacjach wykluczyć.

\section{Jawność grzechu}

Kanon 915 stanowi o niedopuszczeniu do Eucharystii osób, które uporczywie trwają w jawnym grzechu ciężkim („in manifesto gravi peccato obstinate perseverantes"). Przymiotnik manifestus został w polskim przekładzie Kodeksu Prawa Kanonicznego ${ }^{54}$ przetłumaczony jako „jawny”" Sł. Słowo to w języku polskim oznacza „dokonywany albo odbywający się w sposób dla wszystkich widoczny, powszechnie znany, wiadomy; nie maskujący się, nie ukrywany, publiczny; wyraźny, oczywisty"56. Można zatem wskazać na dwie grupy znaczeniowe słowa „jawny” - pierwsza to „powszechnie znany”, druga „dla wszystkich oczywisty”. Podobne są znaczenia łacińskiego przymiotnika manifestum: jawny, widoczny oraz oczywisty, wyraźny ${ }^{57}$.

\footnotetext{
${ }^{54}$ Codex Iuris Canonici auctoritate Ioannis Pauli PP. II promulgatus. Kodeks Prawa Kanonicznego. Przekład polski zatwierdzony przez Konferencję Episkopatu, Poznań 1984.

${ }^{55}$ Tak samo tłumaczy się ów przymiotnik w kan. 1007, $1184 \$ 1,3^{\circ}$, ale w kan. 41 „manifesto” przekładane jest jako „oczywisty”, a w kan. $831 \$ 1,1645 \$ 1$ i 2 to samo słowo tłumaczone jest jako „wyraźnie”.

${ }^{56}$ Mały Słownik Języka Polskiego, red. E. Sobol, Warszawa 1997, s. 279.

${ }^{57}$ Zob. M. Plezia (red.), Słownik łacińsko-polski, t. III, Warszawa 1969, s. 436; A. Jougan, Słownik kościelny łacińsko-polski, Warszawa 1992, s. 405; J. Sondel, Słownik łacińsko-polski dla prawników i historyków, Kraków 1997, s. 605.
} 
W literaturze rozważane jest też inne tłumaczenie tego sformułowania, w którym użyte w kanonie słowo manifesto traktuje się nie jako ablativus przymiotnika manifestus, ale przysłówek manifesto (inna forma tego przysłówka to manifeste). Wówczas kan. $915 \mathrm{w}$ przekładzie na język polski musiałby dotyczyć osób, które „uporczywie trwają w grzechu wyraźnie ciężkim". Takie tłumaczenie istotnie wpływałoby na znaczenie wyrażenia „grzech ciężki”, bowiem w jednym przypadku chodziłoby o grzech, który jest jawny, a więc powszechnie znany, a w drugim o grzech, który jest ewidentnie ciężki ${ }^{58}$.

W pierwszym znaczeniu sens przymiotnika "jawny" skupia się na publicznym charakterze grzechu, jako czegoś, co jest faktycznie rozpowszechnione lub przynajmniej łatwo może być poznane, przynajmniej $\mathrm{w}$ danej wspólnocie eucharystycznej. W tym sensie peccatores manifesti nie odbiegają od dawnej kategorii publice indigni z kan. $855 \$ 1$ KPK z 1917 r., które to wyrażenie widnieje także w kan. $712 \mathrm{KKKW}^{59}$. W tym kontekście znaczeniowym słowa ,jawny” warto zwrócić uwagę na to, że niedopuszczenie osób żyjących w nieprawidłowych (zwanych czasem nieregularnymi ${ }^{60}$ ) związkach do Komunii Świętej uzasadniane było także zgorszeniem: „dopuszczenie ich do Eucharystii wprowadzałoby wiernych w błąd lub powodowałoby zamęt co do nauki Kościoła o nierozerwalności małżeństwa" ${ }^{61}$.

\footnotetext{
${ }^{58}$ Zob. W. Kowal, The Non-Admission..., s. 416-418.

${ }^{59}$ Zob. J. Hendriks, Pecado manifiesto, w: Diccionario General de Derecho Canónico, red. J. Otaduy, A. Viana, J. Sedano, t. VI, Pamplona 2012, s. 56.

${ }^{60} \mathrm{~W}$ urzędowym łacińskim tekście Familiaris consortio użyty jest przymiotnik „abnormis” (nr 79, 80, 85), a w tłumaczeniu włoskim mówi się o „situazioni irregolari”, co na język polski często tłumaczy się, stosując kalkę językową, jako „sytuacje nieregularne”. Wydaje się, że właściwym tłumaczeniem jest „sytuacje nieprawidłowe". Tak zresztą w oficjalnym wydaniu polskim adhortacji apostolskiej.

${ }^{61}$ FC, nr 84. O zgorszeniu także mówi się w Deklaracji Papieskiej Rady ds. Interpretacji Tekstów Prawnych z 24 czerwca 2000 r.: „W rozpatrywanym tu przypadku dopuszczenia do komunii wiernych rozwiedzionych, żyjących w nowych związkach, zgorszenie - pojmowane jako działanie skłaniające innych do zła - dotyczy jednocześnie sakramentu Eucharystii oraz nierozerwalności małżeństwa. Do zgorszenia dochodzi nawet wówczas, gdy takie postępowanie nie budzi już niestety niczyjego zdziwienia”.
} 
Dlatego nawet w stosunku do tych, którzy decydują się na życie we wstrzemięźliwości seksualnej, aby żyjąc w związku tylko cywilnym móc przystępować do Komunii Świętej wyjaśnia się, że mogą oni przystępować do Komunii Eucharystycznej tylko remoto scandalo ${ }^{62}$.

„Zgorszenie jest postawą lub zachowaniem, które prowadzi drugiego człowieka do popełnienia zła"63. I w takim właśnie sensie - a więc rozumiane jako „zły przykład”, „zły wpływ” czy „demoralizacja”, nie zaś jako „oburzenie” wywołane niemoralnym postępkiem, naruszenie czyjegoś poczucia przyzwoitości - trzeba postrzegać zgorszenie w rozumieniu prawa kanonicznego. Zgorszyć kogoś, to znaczy przyczynić się do upadku jego wiary i moralności ${ }^{64}$.

Czy dopuszczenie do Komunii Świętej osób po rozwodzie, które żyją w nowych związkach może stanowić zgorszenie w tym właśnie znaczeniu, czyli prowadzić do przekonania, że Kościół akceptuje wszystkie, bez wyjątku, związki nieprawidłowe i usprawiedliwiać przystępowanie do Eucharystii wszystkich, bez zważania na efekty rozeznania duszpasterskiego? Wydaje się, że takie zagrożenie istnieje, a problem jest przez komentatorów Amoris laetitia dostrzegany ${ }^{65}$. Ale jeśli udałoby się owego niebezpieczeństwa uniknąć - np. przez rzetelną katechezę wszystkich wiernych - jeden z istotnych powodów, dla których odmawia się Eucharystii takim osobom straciłby na znaczeniu ${ }^{66}$.

${ }^{62}$ Dlatego komentatorzy wskazują, że w takich sytuacjach wierni powinni przy-
stępować do Komunii Świętej poza parafią, w której ich stan jest znany. Zob.
F.R. Aznar GiL, Uniones matrimoniales irregulares..., s. 201.
${ }^{63}$ KKK, nr 2284 .
${ }^{64}$ Zob. P. MAJER, Prawo kanoniczne a zgorszenie, Pastores nr 59 (2), 2013 r., s. $127-134$.

${ }^{65}$ Zob. F. Coccopalmerio, Radość miłości..., s. 26.

${ }^{66}$ Warto przypomnieć, że wyrażenie peccatores manifesti znajduje się w kan. 1184 $\$ 1,3^{\circ} \mathrm{KPK}$, w którym zakazuje się jawnym grzesznikom udzielania katolickiego pogrzebu, gdyby budziło to publiczne zgorszenie wiernych. Oznacza to, że sam fakt bycia jawnym grzesznikiem nie jest wystarczającym powodem, by komuś nie przyznać pogrzebu, ale musi zaistnieć rzeczywiste niebezpieczeństwo zgorszenia. Jeżeli nie ma takiego niebezpieczeństwa, pogrzebu odmawiać nie wolno, nawet jeśli ktoś był publicznym grzesznikiem. Zob. P. Majer, Komentarz do kan. 1184, 
Tłumaczenie łacińskiego słowa manifesto na „jawny”, a w dodatku traktowanie go jako synonimu przymiotnika „publiczny” jest uznawane za niewłaściwe ${ }^{67}$. Jest bowiem jeszcze inny sens przymiotnika manifestus, wyrażony w tłumaczeniu tego słowa na polski jako „oczywisty”, czyli jasny, wyraźny, niebudzący wątpliwości, bezsporny, ewidentny ${ }^{68}$. W takim właśnie znaczeniu pojawia się to wyrażenie w nowym kan. $1683,2^{\circ} \mathrm{KPK}$, po niedawnej reformie procesu o stwierdzenie nieważności małżeństwa, wprowadzającym proces skrócony przed biskupem w przypadkach, w których nieważność małżeństwa jest „oczywista”. W tym przypadku nie chodzi o to, że nieważność jest powszechnie znana, ale o to, że nie budzi ona żadnych wątpliwości: każdy człowiek rozumnie oceniający fakty jest przekonany, że dane małżeństwo jest w sposób ewidentny nieważne ${ }^{69}$. Należy zatem zadać pytanie, czy fakt życia po rozwodzie w nowym związku zawsze jest grzechem ciężkim w sposób oczywisty, czyli nie budzący cienia wątpliwości? Wydaje się, że kazusy podawane w adhortacji papieża Franciszka oraz przez jej komentatoró $w^{70}$ nie pozwalają na udzielenie odpowiedzi twierdzącej, a co najmniej skłaniają do refleksji i dostrzeżenia trudności pogodzenia dotychczasowego rozumienia doktryny Kościoła z hermeneutyką osoby proponowaną przez Franciszka.

w: Komentarz do Kodeksu Prawa Kanonicznego, t. III, cz. 2: Księga IV. Uświęcające zadanie Kościoła, red. J. Krukowski, Poznań 2011, s. 401.

${ }^{67}$ Zob. W. Kowal, The Non-Admission..., s. 427.

${ }^{68}$ Zob. też P.L. Travers, «Amoris Laetitia» and Canon 915..., s. 405-406.

${ }^{69}$ Zob. P. Majer, Proces małżeński skrócony przed biskupem, w: Praktyczny komentarz do Listu apostolskiego motu proprio «Mitis Iudex Dominus Iesus» papieża Franciszka, red. P. Skonieczny, Tarnów 2015, s. 168-169.

${ }^{70}$ Zob. A. Muszala, Rozeznawanie..., s. 225-227. Np. czy bez cienia wątpliwości można powiedzieć, że ciężką grzesznicą jest kobieta, która w małżeństwie doświadczała przemocy fizycznej ze strony męża, znajduje ratunek i wsparcie duchowe oraz materialne u innego mężczyzny, z którym po rozwodzie zawiera związek cywilny, wspólnie wychowują dzieci, żyjąc w zgodzie i miłości i bolejąc nad oddaleniem od Eucharystii w życiu wiary, które szczerze pragną prowadzić? 


\section{Konkluzja}

Niezależnie od wątpliwości natury teologicznej - czy to w dziedzinie teologii moralnej, czy zgodności magisterium Franciszka z wcześniejszym nauczaniem Kościoła - nie wydaje się, by kan. 915 stanowił przeszkodę natury prawnej dla dopuszczania do Komunii Świętej, po przeprowadzonym rzetelnym rozeznaniu osobistym i duszpasterskim, niektórych osób, które po rozwodzie cywilnym żyją w nowych związkach i których sytuacja życiowa została oceniona, zgodnie $\mathrm{z}$ nauczaniem adhortacji Amoris laetitia, jako wolna od ciężkiej winy. Trzy przesłanki zawarte w tym przepisie - grzech ciężki, uporczywe trwanie w nim i oczywistość grzechu - w świetle nauczania papieskiego mogą w ogóle nie weryfikować się w szczególnych sytuacjach konkretnych osób. Wówczas kan. 915 nie ma zastosowania.

Należy też pamiętać, iż zakaz dopuszczania do Eucharystii „osób trwających z uporem w jawnym grzechu ciężkim" nie ma też zastosowania w przypadku wątpliwości co do istnienia grzechu ciężkiego

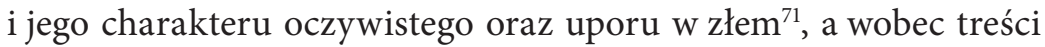
zawartych w posynodalnej adhortacji trudno mówić, by nie pojawiały się poważne wątpliwości co do tego, że każdy rozwiedziony, który zawarł nowy związek, jest publicznym, ciężkim grzesznikiem, który nie ma woli zmiany swej sytuacji ${ }^{72}$.

Dlatego, odpowiadając na pytanie zawarte w tytule niniejszego artykułu, wypada stwierdzić, że po Amoris laetitia kan. 915 nie musi być zmieniany, zachowuje swą aktualność ${ }^{73}$, ale wobec osób rozwiedzionych, które zawarły nowe związki, jego interpretacja musi

${ }^{71}$ Zob. J. Hendriks, Pecado manifiesto..., s. 56.

${ }^{72}$ AL, nr 296 - „trzeba unikać osądów, które nie uwzględniają złożoności różnych sytuacji”.

${ }^{73}$ Kanon, odnosząc się do kategorii osób trwających z uporem w jawnym grzechu ciężkim, nie ogranicza się do tych, którzy żyją w nieuporządkowanych sytuacjach małżeńskich, ale odnosi się m.in. do tych katolików, którzy pełniąc zadania publiczne - np. w sferze politycznej - otwarcie sprzeciwiają się nauczaniu Kościoła, głosując czy podejmując inne działania ułatwiające aborcję. Zob. R.L. Burke, Canon 915: The discipline regarding the denial of Holy Communion to those obstinately persevering in manifest grave sin, Periodica 96 (2007), s. 3-58. 
uwzględniać magisterium papieża Franciszka, tak jak uwzględniała dotychczasowe nauczanie Kościoła.

\section{Did exhortation Amoris laetitia change can. 915 CIC?}

The paper deals with the problem of the relationship between the teaching of Pope Francis regarding the admission to the Eucharist of the divorced persons who have entered into new marriages, and the prescription of can. 915 of the Code of Canon Law, which forbids the admission to Holy Communion of persons who obstinately persist in manifest grave sin.

After presenting the doctrine contained in Amoris laetitia, the author analyses three elements of the hypothesis of can. 915 (grave sin, persistence in sin, and manifest of sin) and formulates the position that the new apostolic exhortation is not contrary to the prescription of can. 915 of the Code of Canon Law. The interpretation of this canon must take into account the magisterium of Pope Francis, just as it took into account the teaching of the Church so far.

SŁowA KLUCzowE: Amoris laetitia; Komunia Święta; Eucharystia; rozwiedzeni w nowych związkach

Keywords: Amoris Laetitia; Holy Communion; Eucharist; divorced and remarried

\section{Nota o AUTORZE}

Ks. DR hab. Piotr Majer, Prof. UCZelni - pracownik naukowo-dydaktyczny na Uniwersytecie Papieskim Jana Pawła II w Krakowie, kierownik Katedry Prawa o Kościelnej Misji Nauczania i Uświęcania na Wydziale Prawa Kanonicznego UPJPII, prezbiter archidiecezji krakowskiej, kanonik Kapituły Metropolitalnej w Krakowie, były kanclerz Kurii Metropolitalnej w Krakowie, konsultor Rady Prawnej Konferencji Episkopatu Polski. 